\title{
ASSESSMENT OF THE CONDITION OF SAMOŁĘSKIE LAKE WATERS
}

\author{
Ewa Osuch ${ }^{1}$, Andrzej Osuch ${ }^{1}$, Stanislaw Podsiadłowski ${ }^{1}$, \\ Piotr Rybacki', Mariusz Adamski ${ }^{1}$, Julianna Ratajczak'
}

\begin{abstract}
1 Biosystems Engineering Institute, Poznań University of Life Sciences, Wojska Polskiego 50, 60-627 Poznań, Poland, e-mail: ewa.osuch@up.poznan.pl, andrzej.osuch@up.poznan.pl, stapod@up.poznan.pl, prybacki@ up.poznan.pl, mariusz.adamski@up.poznan.pl, julianna.ratajczak@wp.pl
\end{abstract}

Received: 2016.02.06

Accepted: 2016.03.04 Published: 2016.04.01

\begin{abstract}
Samołęskie Lake is situated in the Poznań Lakeland in Greater Poland Voivodeship, Szamotuły County, Wronki District. The lake adjoins a little village of Samołęż of about 500 residents. The glacial waterbody of over 30 ha acreage is a typical tunnelvalley lake having a maximum depth of over 22 meters. It predominantly serves fishing and recreation purposes offering a beach and a sailing center. Near the coastline (not in the direct vicinity) there is a farmland. The objective of the dissertation was to assess the quality of Samołęskie Lake waters that was delivered based on the studies carried out in spring and summer, when the waterbody demonstrates excessive fertility. The studies covered the analysis of the basic physical and chemical parameters of the lake water. The measurement was carried out on a fortnight basis by means of a measurement apparatus such as the photometer and the Secchi disc. The collected results are presented with the use of figures later in this paper, whereas their in-depth analysis allowed to compile and formulate conclusions. The results of studies and analyses lay the foundations to state that the quality of Samołęskie Lake waters requires continuous monitoring and application of remedial and rehabilitation measures.
\end{abstract}

Keywords: lake, lake rehabilitation, lake eutrophication.

\section{INTRODUCTION}

Water is the basis of human and other earthly beings' subsistence. About $97 \%$ of water constitute oceans and seas, about $2 \%$ constitute ice sheets and glaciers and $0.6 \%$ are ground waters. All the rest are waters of rivers, lakes and swamps. Despite different states, water is in continuous motion, vaporizes, condenses and precipitates. During the precipitation process water diffuses soil and its temporary overabundance is drained by rivers and gets to lakes and seas. It is a repetitive cycle [Starmach and others 1978]. Lakes are natural water bodies and can have a surface of nearly 1ha up to hundreds of thousands square meters, and the depth reaching 15 hundred meters. The bodies are characterized by slow water exchange and are watered by surficial and ground supplies [Stańczykowska 1997]. The surface of over a half of the Polish lakes does not exceed 5 ha [Kajak
1998], whereas the biggest number of lakes in Poland are situated in the Masurian Lake District [Stańczykowska 1997, Kajak 2001]. Lakes play a very important role both in nature and in human life [Kajak 1998]. It is a natural process that lakes gradually reduce in surface. It takes place very slowly and is virtually unnoticeable in the lifetime of a single generation [Stańczykowska 1997]. The lake eutrophication is a phenomenon based on the increase of organic matter in a waterbody that results in its fertilization. The intensification of the lake eutrophication manifests itself in the enhancement of phytoplankton bloom, development of submerged vegetation, and decrease in water transparency. The excessive lake fertility has negative effect on both the inhabitants of aquatic ecosystem and on economic capability of waterbody use [Lampert and Sommer 2011, Choiński and Kaniecki 1996, Kajak 2001, Żmudziński and others 2002, Podsiadłowski and 
Gołdyn 2009, Pliński 2009]. Unfortunately, as a result of human activity, a number of Polish lakes have undergone eutrophication processes [Harper 1992]. Causes and effects of lake eutrophication process and prevention measures are described in detail in the limnological literature [Olszewski 1971, Kalff 2001, Kubiak and Tórz 2005]. The most apparent deterioration of the lake waters condition has taken place for the last 30 years and was caused by the continuous intensification of agricultural production by mineral fertilizers and crop protection chemicals. It applies to the soil, not diminishing the role of tourism and local industry [Lossow 1998]. Eutrophication is considered one of the biggest threats to the biodiversity of freshwater bodies. Over $85 \%$ of lakes studied in the recent years are characterized by the concentration of phosphorus and transparency, typical of eutrophic water bodies. Numerous latest publications signalize the deteriorative condition of Polish waters [Zdanowski 1983; Hilbricht-Ilkowska 1989; Lossow 1998]. This forces the necessity to seek effective methods of their protection [Balczerzak 2009]. The protection of lakes requires to slower, stop or even reverse the degradative processes and remove their negative effects [Lossow 1995, Lossow and Gawrońska 1998]. The basic, and simultaneously the simplest measure for water protection is to reduce or eliminate the biogenes sources. The degradation stage of some waterbodies is already high and in such cases it is necessary to apply appropriate, and unfortunately expensive, rehabilitation measures [Osuch and others 2015].

\section{OBJECTIVE, SCOPE AND METHODOLOGY}

The objective of the dissertation was to assess the quality of Samołęskie Lake waters the goal was achieved based on the studies carried out in spring and summer, when the waterbody demonstrates excessive fertility. The examined parameters included the concentration of ammonia nitrogen and orthophosphate. The studies were divided into two parts - field and laboratory ones, where the former was performed directly on the lake. The measurements were carried out on a regular fortnight basis on the three lake spots, as indicated in the figure 1, and the study presents the results achieved in each location. Water transparency was examined by means of the Secchi disc immersed in the lake water. In order to carry out the study the disc was slowly immersed in water until it disappeared from view. The concentration of ammonia nitrogen and orthophosphate were examined in laboratory conditions.

The map presents the location of the research stations whose waters were used for the laboratory analyses. Moreover, the study of the research station 2 covered also the definition of the lake water transparency level. Station 1 was located on the fishing bridge, the station 2 was located near the beach, and station 3 adjoined the countryside.

\section{RESULTS AND ANALYSIS}

Samołęskie Lake is one of the 14 waterbodies in Wronki District. It is a glacial flow-through

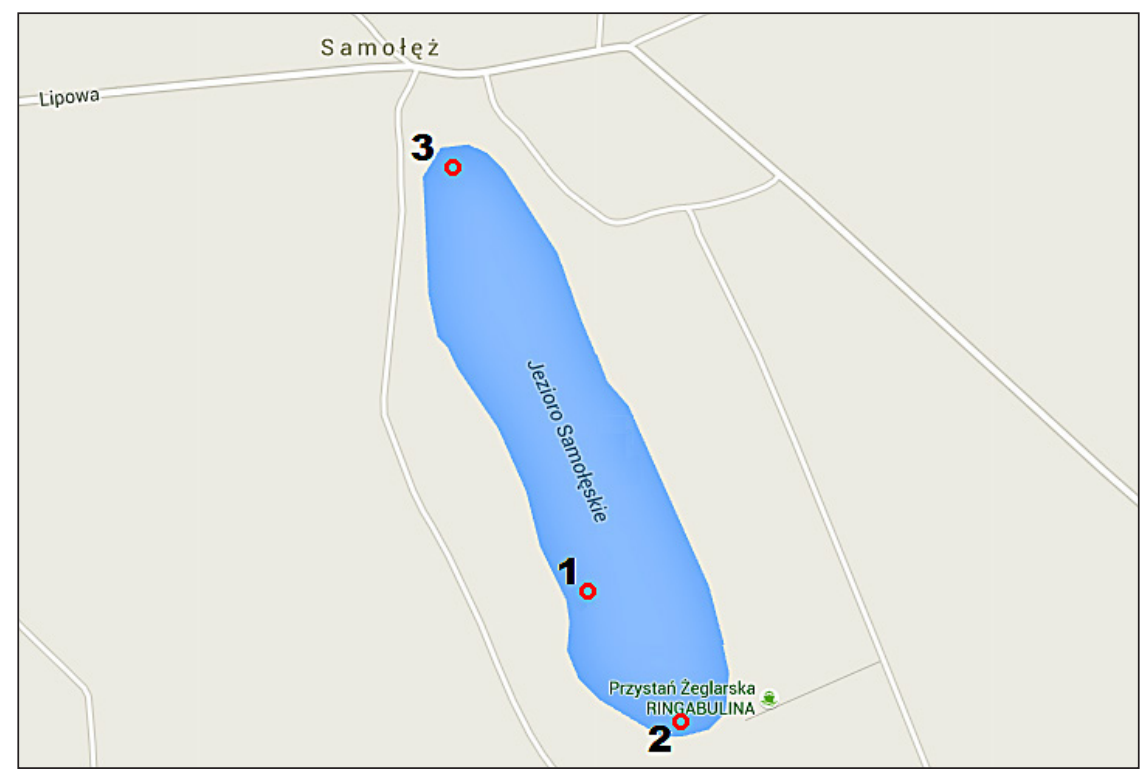

Figure 1. Distribution of the research stations on Samołęskie Lake 
lake being a part of the river Warta basin. The area around the lake is diversified with Samołęż village (of about 500 inhabitants) on the Northern coastline. Almost entire coastline has a natural character. Alongside the eastern and western part of the coastline, however, not in the direct neighborhood, there is a farmland, in turn on its southern bank there is a beach with a sailing center. The waterbody mainly serves fishing purposes and, to a lesser extent, recreation purposes due to its high eutrophication level. It is successively populated with fish by the fishing club that manages the initiative [ $\mathrm{Laz} 2011$ ].

The visibility of the Secchi disc (water transparency) is a rough benchmark of the penetration of solar radiation into water, that is conditioned by the presence of solid particles that either absorb or scatter solar radiation that reaches water. The low transparency of lake waters is one of the first symptoms of the waterbody deteriorative condition to be noticed. The measurements were taken during every study term in every location of the three research stations. Their results laid the foundations for the in-situ analysis of water transparency. Figure 2 presents the achieved results of the Secchi disc visibility in a form of an arithmetic mean of all the research stations.

The data presented in the above figure allow to draw the conclusion that the lake water transparency achieved highest values during the study carried out at the beginning of July, and the lowest at the beginning of September. In the remaining research periods, the transparency value reached the depth of $120 \mathrm{~cm}$. The low water transparency reduces the amount of solar radiation reaching deeper layers of the lake, thus disenabling the development of macrophytes.
The other measurements (of ammonia nitrogen and orthophosphates) were provided in the laboratory based on the photometric analysis carried out by means of PC MultiDirect photometer by Lovibond. Tn the case of all the three research stations the water samples were stored in hermetic plastic containers, and their photometric analyses were carried out the same day they were collected. The averaged results of the concentration analyses of ammonia nitrogen and orthophosphates from all the three stations are presented in the Figures 3 and 4.

Water is a natural source of the generous supplies of free nitorgen $\left(\mathrm{N}_{2}\right)$. Only some of water beings are able to absorb nitrogen in this form. For the water flora, this element is available in a few different forms: nitrite $\left(\mathrm{NO}_{2}-\right)$, nitrate $\left(\mathrm{NO}_{3}\right.$ $-)$, ammonia $\left(\mathrm{NH}_{3}\right)$, and ammonium $\left(\mathrm{NH}_{4}+\right)$. The above-mentioned compounds usually get to surface waters with the influent industrial, domestic, agricultural wastewaters. The excess of the above elements is the reason for the considerable increase in vegetative plankton and causes eutrophication [Chojnacki 1998, Łaz 2011].

As follows from the data presented in Figure 3 , the concentration of ammonia nitrogen in water in all the measurements exceeded $0.15 \mathrm{mg} \mathrm{N} \cdot \mathrm{dm}^{-}$ ${ }^{3}$. The highest concentration was recorded during the studies carried out at the end of August when it amounted to $0.22 \mathrm{mg} \mathrm{N} \cdot \mathrm{dm}^{-3}$. This is the quadrupled valued of this parameter since its critical value amounts to $0.2 \mathrm{mg} \mathrm{N} \cdot \mathrm{dm}^{-3}$.

The distribution of phosphorus in water is inversely proportional to the content of oxygen in water. The element gets to the surface waters with the precipitation and basin inflows. Another factor affecting the concentration of phosphorus forms are

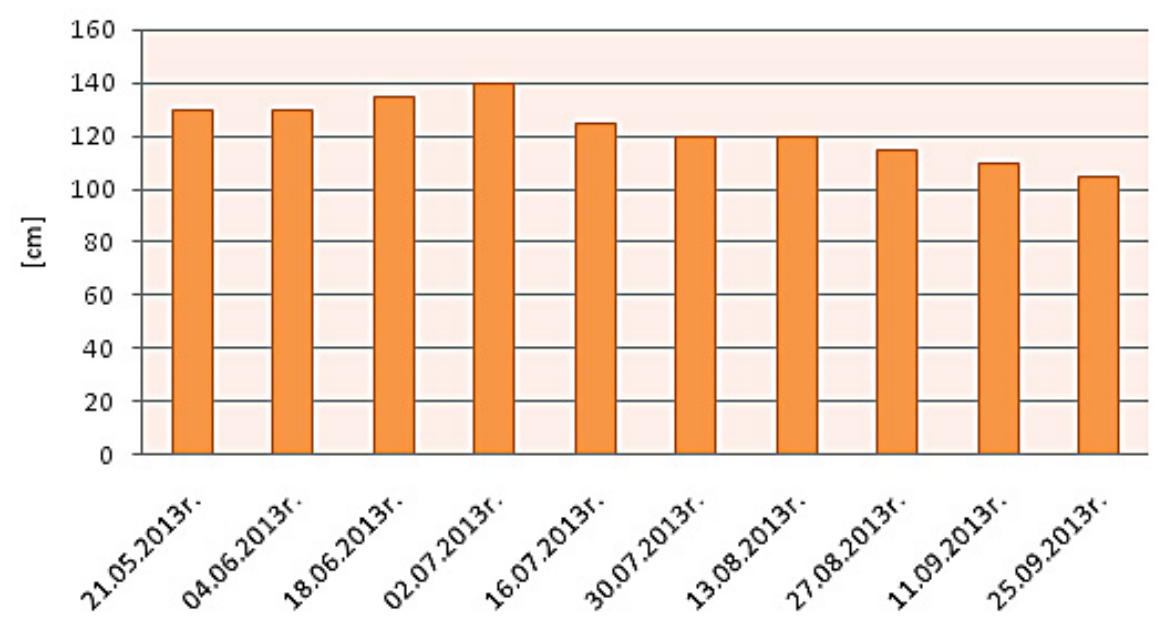

Figure 2. Water transparency of Samołęskie Lake 


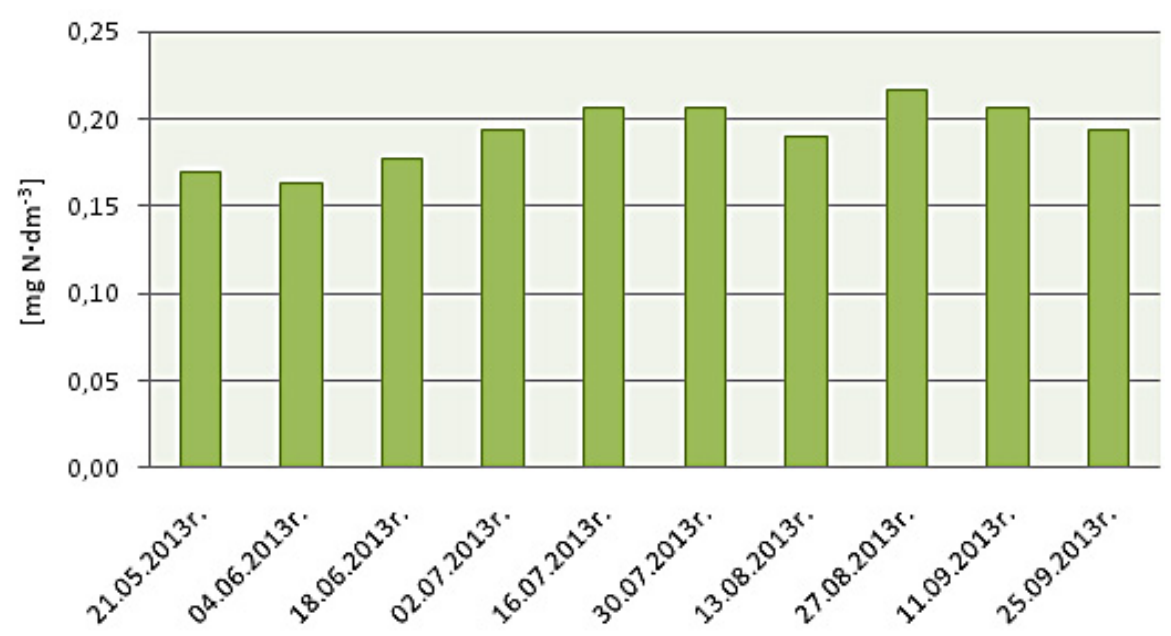

Figure 3. The concentration of ammonia nitrogen in the water of Samołęskie Lake

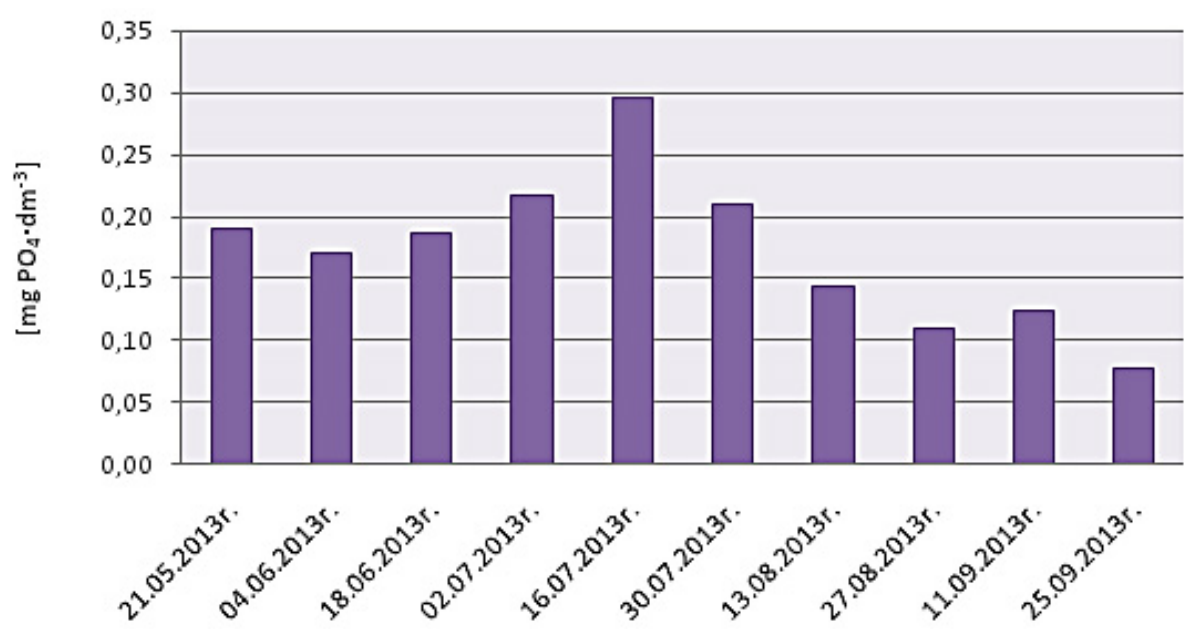

Figure 4. The concentration of orthophosphate in the water of Samołęskie Lake

ground and surface water inflows or the distribution of water beings [Chojnacki 1998, Łaz 2011].

The concentration of orthophosphates in the entire measurement cycle exceeded the critical value of this parameter, i.e. $0.1 \mathrm{mg} \mathrm{PO} \cdot \mathrm{dm}^{-3}$. The highest content of orthophosphaes was recorded during the studies carried out on July 16, 2013, and amounted to nearly $0.3 \mathrm{mg} \mathrm{PO}_{4} \cdot \mathrm{dm}^{-3}$.

\section{CONCLUSIONS}

The studies and analysis of their results allow to draw conclusions as follows:

1. In the majority of the measurements the concentration of ammonia nitrogen in water was at an acceptable level, however, there were 4 tests during which the value was exceeded. This might be the evidence of the periodic inflow of wastewater from the nearby recreation area.
2. Water transparency level is low, which is the evidence for the deteriorative ecological condition of the lake.

3. The concentration of orthophosphates in water throughout the study exceeded the so called "critical value", which confirms the progressive nature of the lake eutrophication process.

4. The results of the studies and analyses allow to state that the quality of Samołęskie Lake waters is not optimistic and therefore requires continuous monitoring and application of remedial and rehabilitation measures.

\section{REFERENCES}

1. Balcerzak W. 2009. Eutrofizacja wód stojących prognozowanie i wpływ na technologię uzdatniania wody. Series: inżynierie środowiska, Kraków.

2. Choiński A., Kaniecki A., 1996. Wielka encyklopedia geografii świata. Wody ziemi. Publ. Kur- 
pisz s.c. Volume 4, Poznań, 39-40.

3. Chojnacki J.C. 1998. Podstawy ekologii wód. Publishing House of Agricultural University of Szczecin, Szczecin.

4. Harper D. 1992. Eutrophication of freshwaters: principles, problems and restoration. Chapman and Hall, London.

5. Hillbricht-Ilkowska A. 1989. Różnorodność biologiczna siedlisk słodkowodnych - problemy, potrzeby, działania. Idee Ekologiczne, Ser. Szkice 13/7, 13-55.

6. Kajak Z., 1998. Hydrobiologia - limnologia. Ekosystemy wód śródlądowych. Polish Scientific Publishers PWN, Warsaw.

7. Kajak Z. 2001. Eutrofizacja jezior. Polish Scientific Publishers PWN, Warsaw.

8. Kalff J. 2001. Limnology. Protice Hall, New Jersey.

9. Kubiak J., Tórz A. 2005. Eutrofizacja. Podstawowe problemy ochrony wód jeziornych na Pomorzu Zachodnim. Słupskie Prace Biologiczne 2, 17-36.

10. Lampert W., Sommer U. 2001. Ekologia wód śródlądowych, wyd. PWN, Warsaw.

11. Lossow K. 1995. Zanikajace jeziora. Ekoprofit, 07/08, 40-45.

12. Lossow K. 1998. Ochrona i rekultywacja jezior - teoria i praktyka. Idee ekologiczne. Ser. Szkice 13/7, 55-71.

13. Lossow K., Gawrońska H. 1998. External input to Lake Wadag - effective and estimate loadings. Pol. J. Envir. Stud., 7(2), 95-98.
14. Łaz M. 2011. Charakterystyka Jeziora Samołęskiego. BSc thesis. Poznań.

15. Olszewski P. 1971. Trofia a saprobia. Zeszyty Naukowe WSR in Olsztyn Ser. C, Supl. 3, 5-14.

16. Osuch E., Osuch A., Podsiadłowski S., Przybył J., Walkowiak R. 2015. Zmienność emisji gazów podczas aeracji pulweryzacyjnej. [In:] M. Lipiński, J. Przybył (Eds.) Aktualne problemy inżynierii biosystemów. University of Life Sciences Publishing House, Poznań, 44-52.

17. Pliński M. 2009. Przyczyny i skutki zakwitów sinicowych. IV Ogólnopolskie Warsztaty Sinicowe "Toksyczne zakwity sinic w wodach słodkich i słonawych". The Institute of Oceanography of the University of Gdańsk, Regionalne Centrum Sinicowe, Polskie Towarzystwo Hydrobiologiczne, Gdynia, 4-8.

18. Podsiadłowski S., Gołdyn R. 2009. Metody zrównoważonej rekultywacji jezior. Wielkopolski Biuletyn Ekologiczny 3/2009.

19. Stańczykowska A. 1997. Ekologia naszych wód, Wydawnictwa Szkolne i Pedagogiczne, Warsaw.

20. Starmach K., Wróbel S., Pasternak K. 1978. Hydrobiologia, Polish Scientific Publishers PWN, Warsaw.

21. Zdanowski B. 1983. Chlorophyll content and visibility of Secchi's disc in 46 lakes. Ekol. Pol., 31, 333-352.

22. Żmudziński I., Kornijów R., Bolałek A., Górniak A., Olańczuk-Neyman K,. Pęczalska A., Korzeniewski K. 2002. Słownik hydrobiologiczny. Polish Scientific Publishers PWN, Warsaw, 65-192. 